\title{
Simultaneous High Performance Liquid-Chromatographic Determination of Carbamazepine, Carbamazepine-10,11-epoxide, Ethosuximide, Phenobarbital, Phenytoin, Primidone and Phenylethylmalonamide in Plasma
}

\author{
By H. M. Neels, J. A. Totté, R. M. Verkerk, A.J. Vlietinck and S. L. Scharpé \\ Department of Pharmaceutical Sciences, University of Antwerp
}

(Received January 18/December 17, 1982)

Summary: A common methodology is reported for the determination of five major anticonvulsants (carbamazepine, ethosuximide, phenobarbital, phenytoin, primidone) and their active metabolites (carbamazepine10,11 -epoxide, phenylethylmalonamide) in $30 \mu \mathrm{l}$ of plasma.

After a single step of deproteinisation and extraction with acetonitrile, leading to an almost complete recovery of all the analytes, $5 \mu \mathrm{l}$ is injected on a reversed-phase column (Lichrosorb RP-18, $5 \mu \mathrm{m}$ ). The anticonvulsants are eluted isocratically at a column temperature of $50^{\circ} \mathrm{C}$ with a mobile phase consisting of acetonitrile/phosphate buffer pH 6.9 (40/60 by vol), and monitored at $208 \mathrm{~nm}$. Quantitation, using peak height or peak area, is based on the ratio of analyte to internal standard (allylisobutylbarbital) referenced to a serum-based multiple drug standard.

The composition and $\mathrm{pH}$ of the mobile phase, temperature of the column, choice of wavelength of detection and size of the column material are crucial for the optimal separation of these five drugs and their two active metabolites in a chromatographic time of only $12 \mathrm{~min}$, without sacrificing high sensitivity and column life.

Gleichzeitige Bestimmung von Carbamazepin, Carbamazepin-10,11-epoxid, Ethosuximid, Phenobarbital, Phenytoin, Primidon und Phenylethylmalonamid im Plasma durch Hochleistungsflüssigchromatographie

Zusammenfassung: Eine gemeinsame Methodologie für die Bestimmung der fünf wichtigsten Antikonvulsiva (Carbamazepin, Ethosuximid, Phenobarbital, Phenytoin, Primidon) und ihrer aktiven Metabolite (Carbamazepin-10,11-epoxid, Phenyethylmalonamid) in $30 \mu$ l Plasma wird beschrieben.

Nach Enteiweißung und Extraktion mit Acetonitril mit nahezu vollständiger Wiederfindung alle Analyte werden $5 \mu \mathrm{l}$ in eine ,reversed phase"-Säule (Lichrosorb RP-18, $5 \mu \mathrm{m}$ ) injiziert. Die Antikonvulsiva werden isokratisch bei einer Säulentemperatur von $50^{\circ} \mathrm{C}$ mit Acetonitril/Phosphatpuffer $\mathrm{pH} 6,9$ (Volumina, $40+60$ ) eluiert und durch UV-Absorption bei $208 \mathrm{~nm}$ nachgewiesen.

Die quantitative Auswertung über Peak=Höhe und -Fläche beruht auf dem Verhältnis von Analyt zu innerem Standard (Allylisobutylbarbital), bezogen auf einen Viel-Drogen-Standard auf Serumbasis.

Zusammensetzung und pH der mobilen Phase, Säulentemperatur, Wahl der Wellenlänge für den Nachweis und Größe des Säulenmaterials sind für eine optimale Trennung der fünf Pharmaka und ihrer beiden aktiven Metabolite bei einer Chromatographiedauer von nur 12 Minuten, ohne hohe Empfindlichkeit und Lebensdauer der Säule zu schmälern, von entșcheidender Bedeutung.

\section{Introduction}

Since plasma concentrations of anticonvulsant agents show an accurate correlation with treatment efficacy, there is increasing interest in analytical methods suitable for large clinical populations. Radio-immuno-assay, enzyme-immuno-assay, spectrometry, gas-liquid-(GLC) and high-performance liquid chromatography (HPLC) are used for this purpose. 
Usually several components in a mixture must be analysed. Immunological methods are less convenient because separate analyses must be performed for each drug, and cross-reactivity may also occur. Chromatographic methods guarantee greater selectivity and they have the advantage of rapid and simple operation. A preliminary extraction of relatively large quantities of biological material is inevitable when the GLC method is used, which pleads in favour of HPLC methods.

Several HPLC methods have recently been reported for the analysis of anticonvulsant drugs, applied either to the assay of one specific anticonvulsant $(1-4)$, or to the simultaneous determination of several anticonvulsants $(5-11)$.

In an attempt to select a convenient method for the therapeutic monitoring in plasma of mixtures of the common anticonvulsants, ethosuximide, carbamazepine, phenobarbital, phenytoin, primidone and their active metàbolites (phenylethylmalonamide, carbamazepine-10,11-epoxide), we have evaluated several high-performance liquid chromatographic methods in our daily routine during a period of three years. In our hands, various recently developed procedures $(6,9,11)$ are appropriate, but we propose several modifications with emphasis on simultaneous determination of active metabolites, easy operation, short chromatographic time, high sensitivity, long column life, and low cost.

\section{Materials and Methods}

\section{Apparatus}

We used a high performance liquid chromatographic system (Waters Associates, Milford, MA 01757, U.S.A.), consisting of a Model 45 solvent-delivery system, a Model 450 variable wavelength ultraviolet absorbance detector, a Model (CV-6UHP. N 607000 psi manual sample injection Valve (Valco Instruments Company, Houston, TX 77024, U.S.A.). The column was a $300 \mathrm{~mm} \times 4.6 \mathrm{~mm}$ i. d. Li-Chroma tubing, packed with a $5 \mu \mathrm{m}$ Lichrosorb RP-18 (Merck, Darmstadt, F.R.G.). The column was packed using a Model 705 stirred-slurry column packer (Micromeritics Instruments Corporation, Norcross, GA 30093, U.S.A.) and then mounted in a temperature-controlled oven. The recorder was a type BD 41 Model Kipp (Kipp and sons, Delft, The Netherlands).

For the solvent precipitation of the serum proteins we used a microcentrifuge, Model Select-a-Fuge 24, obtained from the Allen Medical Instrument Division, Bio-Dynamics Inc., Santa Ana, CA, U.S.A.

Reagents and standards

All chemicals used were of reagent grade. Distilled water was used throughout.

Mobile phase buffer: this is a degassed solution of $40 \mathrm{ml}$ of acetonitrile (Gold label, Aldrich, Beerse, Belgium) in $60 \mathrm{ml}$ of phosphate buffer (pH 6.9).
Phosphate buffer: add $0.5 \mathrm{~mol} / \mathrm{KOH}$ to a solution of $1.36 \mathrm{~g}$ $\mathrm{KH}_{2} \mathrm{PO}_{4}$ in $800 \mathrm{ml} \cdot \mathrm{H}_{2} \mathrm{O}$ until a $\mathrm{pH}$ of 6.9 is reached, and dilute to $1000 \mathrm{ml}$ with distilled $\mathrm{H}_{2} \mathrm{O}$.

Drug standards: phenobarbital, allylisobutylbarbital and phenytoin were obtained from Siegfried AG (Switzerland), primidone and phenylethylmalonamide were a gift from ICI, Brussels (Belgium); ethosuximide from Parke Davis and Ca., Bornem (Belgium); carbamazepine and carbamazepine-10,11-epoxide were a gift from Ciba-Gẹigy, Brusssels (Belgium).

\section{Procedure}

Add $30 \mu \mathrm{l}$ of acetonitrile containing $750 \mathrm{ng}$ of allylisobutylbarbital (as an internal standard) to $30 \mu \mathrm{l}$ of serum or plasma in an Eppendorf $1.5 \mathrm{ml}$ polypropylene microtube. Vortex, mix the mixture for $10 \mathrm{~s}$, then centrifuge at $8000 \mathrm{~min}^{-1}(5400 \mathrm{~g})$ for $5 \mathrm{~min}$. Inject about $5 \mu$ of the supernate directly onto the column and elute with the mobile phase at a flow rate of $0.8 \mathrm{ml} / \mathrm{min}$ (pressure: $1000 \mathrm{psi}$ ) and a column temperature of $50^{\circ} \mathrm{C}$. With deteriorating. columns, however, a better separation can be achieved at a flow rate of $0.6 \mathrm{ml} / \mathrm{min}$ (pressure: $800 \mathrm{psi}$ ) and a colürmn temperature of $30^{\circ} \mathrm{C}$. The UV absorption is registered at $208 \mathrm{~nm}$ at a sensitivity setting of $0.04 \mathrm{~A}$ full scale. Concentrations of phenobarbital higher than $25 \mathrm{mg} / 1$ were measured at $0.1 \mathrm{~A}$ full scale.

\section{Results}

We evaluated several chromatographic conditions based on the procedures described by Soldin et al. (6) and Kabra et al. (8) using a $300 \mathrm{~mm} \times 4.0 \mathrm{~mm}$ i.d. RP-18 $10 \mu \mathrm{m}$ column. By extending the column length to $600 \mathrm{~mm}$, fifteen anticonvulsants may be separated using the conditions reported in the former method. As both the analysis time and the high pressure made the method less applicable for routine analysis, we decided to determine the optimal analytical variables for a simultaneous analysis of five common anticonvulsants and two active metabolites using the aforementioned $300 \mathrm{~mm}$ columin.

\section{Optimum conditions}

The composition of the mobile phase, the $\mathrm{pH}$ of the mobile phase and the temperature of the column were varied to obtain optimal chromatographic conditions. The most satisfactory separation of phenylethylmalonamide, primidone, ethosuximide and phenobarbital from serüm components e. g. creatinine and uric acid was obtained at room temperature when the $\mathrm{pH}$ of the phosphate buffer component of the eluent was about 6.9 , and the ratio of the buffer to acetonitrile was $60: 40$ by volume.

Increasing the temperature to $50^{\circ} \mathrm{C}$ provided an adequate separation of phenytoin and carbamazepine with acceptable loss of resolution between ethosuximide and primidone. Lowering the temperature below $40^{\circ} \mathrm{C}$ resulted not only in a loss of resolution of carbamazepine and phenytoin but also in longer retention times. The preferred temperature 
was therefore $50^{\circ} \mathrm{C}$. A flow rate of $0.8 \mathrm{ml} / \mathrm{min}$ for the mobile phase resulted in an analysis time of 12 min at $50^{\circ} \mathrm{C}$ (fig. 1 ).

Using this conditions we can inject 400 samples of $5 \mu \mathrm{l}$ deproteinised serum without loss of resolution or peak broadening.

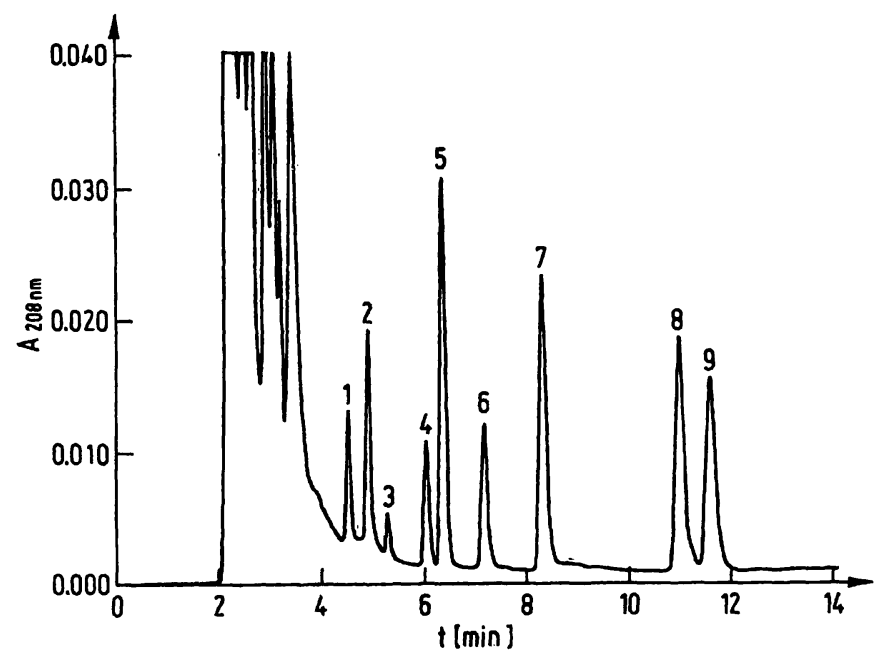

Fig. 1. Chromatogram of the serum used for the precision study given in table 1 . The spiked serum contained per liter: $10 \mathrm{mg}$ of phenylethylmalonamide (1), $12.3 \mathrm{mg}$ of primidone (2), $40 \mathrm{mg}$ of ethosuximide (3), $20 \mathrm{mg}$ of phenobarbital (5), $3.8 \mathrm{mg}$ of carbamazepine-10,11-epoxide (6), $19.2 \mathrm{mg}$ phenytoin (8), $7.6 \mathrm{mg}$ of carbamazepine (9). Peak 7 represents the internal standard. For this analysis the serum was supplemented with $10 \mathrm{mg} / \mathrm{l}$ 4-hydroxy-phenytoin (4), an inactive metabolite accumulating in uraemic patients.

\section{UV-detection}

A detector wavelength of $208 \mathrm{~nm}$ was chosen after careful study of the UV-spectra of the anticonvulsants at their therapeutic and subtherapeutic concentrations (fig. 2). Although it has been reported that the sensitivity of determination of carbamazepine10,11-epoxide is $1 / 15$ of that of carbamazepine at $254 \mathrm{~nm}$ (1), this metabolite was easily detected in the nanogram range at $208 \mathrm{~nm}$; this was achieved with an improved UV-detection, using a variable wavelength spectrophotometer, equipped with a time constant and heat exchangêr, which substantially reduce the instrumental noisẹ.

For the $5 \mu \mathrm{l}$ sample, the detection limit of the drugs examined is less than $1 \mathrm{mg} / \mathrm{l}$ (range 0.3 to $0.9 \mathrm{mg} / \mathrm{l}$ ), except for ethosuximide for which the detection limit is $3 \mathrm{mg} /$.

\section{Quantitation}

The chromatogram was quantitated by measuring the ratio of drug to internal standard, based on peak height or peak area. Both methods were quite satis-

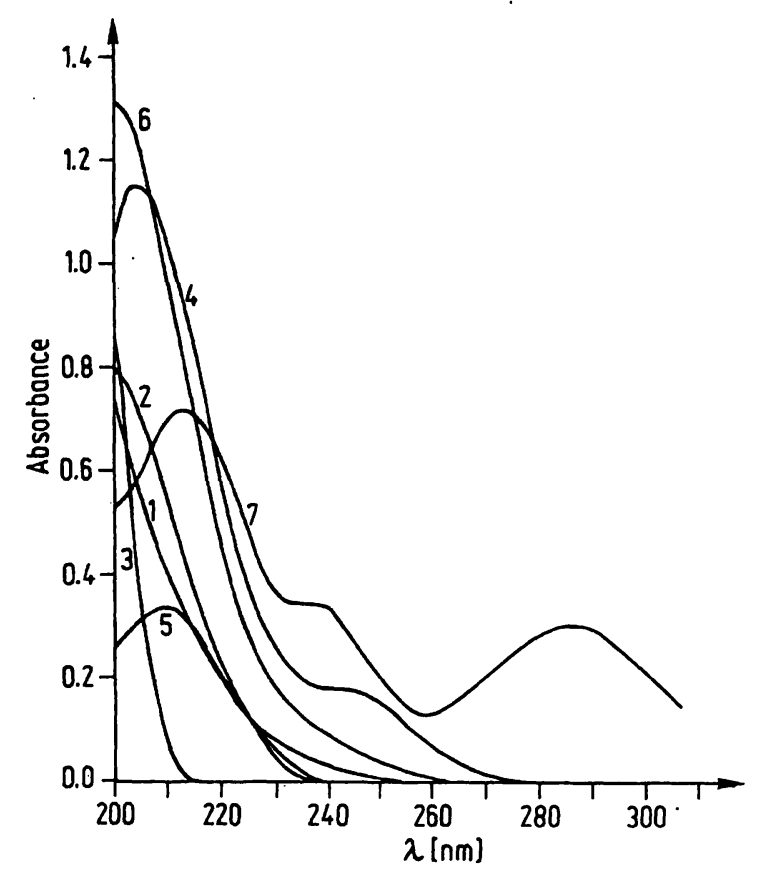

Fig. 2. Ultra-violet spectra of some anticonvulsants and their metabolites at therapeutic or subtherapeutic concentrations.

(1) phènylethylmalonamide $10 \mathrm{mg} / 1$ (2) primidone $12.3 \mathrm{mg} / \mathrm{l}$ (3) ethosuximide $40 \mathrm{mg} /$ (4) phenobarbital $20.0 \mathrm{mg} / \mathrm{l}(5)$ carbamazepine-10,11-epoxide $3.8 \mathrm{mg} / \mathrm{l}$ (6) phenytoin $19.2 \mathrm{mg} / \mathrm{l}(7)$ carbamazepine $7.6 \mathrm{mg} /$.

factory for this analysis. In every single run a serumfree standard of anticonvulsants and metabolites is run with an appropriate control serum in order to monitor retention times and to calculate relative response factors.

The investigation of linearity was carried out in the range of $1-50 \mathrm{mg} / \mathrm{l}$, except for ethosuximide $(1-200 \mathrm{mg} / 1)$. The results showed good linearity in this range.

\section{Precision}

The precision of the method was assessed by repeat. ed analysis of pooled sera containing a standard mixture of the drugs and the active metabolites being investigated. As shown in table 1, within day precision varied between $2.3 \%$ and $6.8 \%$, day-to-day precision between $3.2 \%$ and $7.9 \%$.

\section{Recovery}

The recovery from serum was checked by spiking a drug-free serum with five different concentrations of anticonvulsant drugs and active metabolites. Results were expressed as fractions of the peak heights obtained by the direct injection of the serum-free standards. As shown in table 2, absolute recoveries of the drugs range from 0.93 to 1.03 , whereas absolute recoveries of the active metabolites varied from 0.91 to 1.07 . 
Tab. 1. Precision for measurement of anticonvulsant drugs in plasma

\begin{tabular}{llllll}
\hline & $c(\mathrm{mg} / \mathrm{l})$ & \multicolumn{2}{c}{ Within day } & \multicolumn{2}{c}{ Day to day } \\
& & & $\begin{array}{c}\mathrm{CV} \\
(\%)\end{array}$ & $\mathrm{n}$ & $\begin{array}{c}\mathrm{CV} \\
(\%)\end{array}$ \\
\hline $\begin{array}{l}\text { Phenylethyl- } \\
\quad \text { malonamide }\end{array}$ & 10 & 10 & 6.8 & 15 & 7.9 \\
$\begin{array}{l}\text { Primidone } \\
\text { Ethosuximide }\end{array}$ & 12.3 & 10 & 5.2 & 15 & 6.2 \\
Phenobarbital & 40 & 10 & 2.9 & 15 & 3.9 \\
Carbamazepine-10,11- & 20 & 10 & 2.3 & 15 & 3.2 \\
$\quad$ epoxide & 3.8 & 10 & 4.5 & 15 & 5.2 \\
Phenytoin & 19.2 & 10 & 3.7 & 15 & 4.4 \\
Carbamazepine & 7.6 & 10 & 4.1 & 15 & 5.4 \\
\hline
\end{tabular}

Tab. 2. Recovery of anticonvulsants from plasma

\begin{tabular}{|c|c|c|c|}
\hline & $\begin{array}{l}\text { Added } \\
(\mathrm{mg} / \mathrm{l})\end{array}$ & $\begin{array}{l}\text { Recovered } \\
(\mathrm{mg} / \mathrm{l})\end{array}$ & $\begin{array}{l}\text { Recovery } \\
\text { (fraction) }\end{array}$ \\
\hline Phenylethylmalonamide & $\begin{array}{r}2.0 \\
4.0 \\
6.0 \\
8.0 \\
10.0\end{array}$ & $\begin{array}{r}1.9 \\
3.9 \\
5.5 \\
7.4 \\
10.8\end{array}$ & $\begin{array}{l}0.95 \\
0.98 \\
0.91 \\
0.93 \\
1.08\end{array}$ \\
\hline Primidone & $\begin{array}{r}3.1 \\
4.1 \\
6.2 \\
8.1 \\
12.3\end{array}$ & $\begin{array}{r}3.0 \\
4.0 \\
6.0 \\
7.8 \\
12.5\end{array}$ & $\begin{array}{l}0.96 \\
0.98 \\
0.97 \\
0.96 \\
1.02\end{array}$ \\
\hline Ethosuximide & $\begin{array}{l}10.2 \\
13.6 \\
20.4 \\
40.8 \\
59.0\end{array}$ & $\begin{array}{l}10 \\
13.7 \\
20.2 \\
41.3 \\
57.8\end{array}$ & $\begin{array}{l}0.98 \\
1.01 \\
0.99 \\
1.01 \\
0.98\end{array}$ \\
\hline Phenobarbital & $\begin{array}{r}5.0 \\
7.3 \\
10.0 \\
19.8 \\
21.8\end{array}$ & $\begin{array}{c}4.8 \\
6.8 \\
9.6 \\
20 \\
23\end{array}$ & $\begin{array}{l}0.96 \\
0.93 \\
0.96 \\
1.01 \\
1.05\end{array}$ \\
\hline $\begin{array}{l}\text { Carbamazepine-10,11- } \\
\text { epoxide }\end{array}$ & $\begin{array}{l}0.95 \\
1.2 \\
1.9 \\
2.9 \\
3.8\end{array}$ & $\begin{array}{l}0.86 \\
1.3 \\
2.0 \\
2.6 \\
3.9\end{array}$ & $\begin{array}{l}0.91 \\
1.08 \\
1.05 \\
0.90 \\
1.03\end{array}$ \\
\hline Phenytoin & $\begin{array}{r}4.8 \\
6.4 \\
9.6 \\
14.9 \\
19.2\end{array}$ & $\begin{array}{r}4.6 \\
6.3 \\
9.2 \\
14.3 \\
18.6\end{array}$ & $\begin{array}{l}0.96 \\
0.98 \\
0.96 \\
0.96 \\
0.97\end{array}$ \\
\hline Cärbamazepine & $\begin{array}{l}1.9 \\
2.5 \\
3.8 \\
7.0 \\
7.6\end{array}$ & $\begin{array}{l}1.8 \\
2.4 \\
3.8 \\
7.1 \\
7.8\end{array}$ & $\begin{array}{l}0.95 \\
0.96 \\
1.00 \\
1.02 \\
1.03\end{array}$ \\
\hline
\end{tabular}

\section{Interferences}

Potential interference by currently described drugs was investigated by chromatographing each drug.

Table 3 lists the relative retention time of the components tested. The retention time of the internal standard allylisobutylbarbital was assignêd a value of 100 .

Good practice in drug monitoring involves the availability to the laboratory of complete information about the medication taken by the patient. As can be seen from table 3 some co-elutions cannot be ex-

Tab. 3. Relative retention times (Internal standard $=100$ )

\begin{tabular}{|c|c|}
\hline First serum component & 34 \\
\hline Uric acid & 40 \\
\hline Acetylosalicylic acid & 41 \\
\hline Hippuric acid & 44 \\
\hline Amphetamine & 48 \\
\hline Creatinine & 49 \\
\hline Last serumin component & 55 \\
\hline Acetaminophen & 57 \\
\hline Cimetidine & 58 \\
\hline Phenylethylmalonamide & 61 \\
\hline Barbital & 63 \\
\hline Primidone & 64 \\
\hline Ethosuximide & 66 \\
\hline Allobarbital & 68 \\
\hline 4-Hydroxyphenytoin & 72 \\
\hline Antipyrine & 74 \\
\hline Phenobarbital & 76 \\
\hline Trimethadione & 78 \\
\hline Alloisopropylbarbital & 81 \\
\hline Ethylphenylhydantoin & 83 \\
\hline Carbamazepine-10,11-epoxide & 87 \\
\hline Cyclobarbital & 92 \\
\hline Aminopyrine & 98 \\
\hline Phensuximide & 102 \\
\hline Acetophenetidine & 108 \\
\hline Paramethadione & 113 \\
\hline Beclamide & 125 \\
\hline Amobarbital & 126 \\
\hline Phenytoin & 127 \\
\hline Mephenytoin & 129 \\
\hline Mephobarbital & 131 \\
\hline Pentobarbital & 132 \\
\hline Carbamazepine & 135 \\
\hline Ethylphenacemide & 140 \\
\hline Thiopentat & 146 \\
\hline Hexobarbital & 150 \\
\hline Secobarbital & 155 \\
\hline Clomethiazole & 157 \\
\hline Nitrazepam & 158 \\
\hline Methsuximide & 164 \\
\hline Papaverine & 166 \\
\hline Codeine & 170 \\
\hline Theophylline & 172 \\
\hline Clonazepam & 174 \\
\hline Oxazepam & 175 \\
\hline Cyheptamide & 189 \\
\hline Chlordiazepoxide & 208 \\
\hline $\begin{array}{l}\text { Methaqualone } \\
\text { Diazepam }\end{array}$ & 242 \\
\hline Diazepam & did not elute \\
\hline
\end{tabular}


cluded. With the aid of this table it is possible (for the user of this HPLC procedure) to identify possible interferences. Special attention must be paid to the interference of antipyrine in the quantification of phenobarbital. The chromatogram of metabolites shows that doubling the column length and changing the operating temperature can be used as final refinements in the quantification of the drugs.

\section{Discussion}

Soldin et al. (6) and Kabra et al. (8) described the use of reversed-phase HPLC for the simultaneous determination in serum of phenobarbital, phenytoin, primidone, ethosuximide and carbamazepine. Later Kabra et al. (9) extended their method to the analysis of phenylethylmalonamide, mephenytoin and its active metabolite 5-ethyl-5-phenylhydantoin. Finally Soldin (11) reported the use of radial compression columns.

In these and our procedure, the sera are deproteinised by adding an equal amount of acetonitrile to the samples, followed by centrifugation in polypropylene tubes at a relative high centrifugal force to obtain a complete precipitation of serum proteins. In order to extend the useful life of the column we prefer to inject a small sample volume $(5 \mu \mathrm{l})$ instead of $20 \mu \mathrm{l}(8,9)$.

In his first method Soldin et al. (6) described the use of a mobile phase consisting of an equivolume mixture of potassium phosphate buffer $(\mathrm{pH}=8.0)$ and

\section{References}

1. Eichelbaum, M. \& Bertilsson, L. (1975) J. Chromatogr. 103, $135-140$.

2. Kabra, P. \& Marton, J. (1976) Cliñ. Chem. 22, 1070-1072.

3. Mihaly, G., Philips, J., Louis, W. \& Vajda, F. (1977) Clin. Chem. 23, 2283-2287.

4. Kumps, A., Mardens, Y. \& Scharpé, S. (1980) In: Antiepileptic therapy: Advances in Drug Monitoring (Johannessen, S. I., Morselli, P. L., Pippenger, C. E., Richens, A., Schmidt, D. \& Meinardi, H., eds.) Raven Press, New York, pp. 341347. acetonitrile, which resulted in a serious deterioration of the column packing material due to the alkaline $\mathrm{pH}$ of the eluent.

The mobile phase of their new system (11), consisting of phosphate buffer $(\mathrm{pH}=6.7)$ and acetonitrile (52.5/47.5 by volume), guarantees a longer column life, but in both methods the primidone metabolite phenylethylmalonamide interferes with the analysis of primidone, which results in falsely elevated levels of primidone. The use of a $\mathrm{pH} 4.4$ phosphate buffer, however, which is proposed by Kabra et al. (8) necessitated the restriction of the ratio of acetonitrile/ phosphate buffer to about $20 / 80$ parts by vol. in order to obtain a good separation between ethosuximide, primidone and phenylethylmalonamide. Furthermore, using these conditions, a pressure of 11 $\mathrm{MPa}$ (1600 psi) had to be maintained, resulting in a flow rate of $3.0 \mathrm{ml} / \mathrm{min}$, in order to restrict the analysis time to about $14 \mathrm{~min}$ at an optimum column temperature of $50^{\circ} \mathrm{C}$. To resolve also the active metabolite of carbamazepine, carbamazepine-10,11-epoxide, and to make the method more suitable for routine analysis, we propose that the anticonvulsants be eluted with a mobile phase consisting of acetonitrile/phosphate buffer ( $\mathrm{pH} 6.9)(40 / 60$ by vol) at a flow-rate of $0.8 \mathrm{ml} / \mathrm{min}(1000 \mathrm{psi})$ and a column temperature of $50^{\circ} \mathrm{C}$; this requires only $12 \mathrm{~min}$ for completion. Further we monitor the column effluent at $208 \mathrm{~nm}$ rather than at $195 \mathrm{~nm}$, not only because of the absorption maxima of the anticonvulsants but also to prolong the useful life of the UV-lamp of the detector. Finally we propose that the $10 \mu \mathrm{m}$ smallparticle column material be replaced by $5 \mu \mathrm{m}$ particles to increase column efficiently.
5. Adams, R. \& Vandemark, F. (1976) Clin. Chem. 22, 25-31. 6. Soldins, S. \& Hill, J. (1976) Clin. Chem. 22, 856-859.

7. Adams, R. (1977) Adv. Chromatogr. 15, 131-168.

8. Kabra, P., Stafford, B. \& Marton, L. (1977) Clin. Chem. 23, 1284-1288.

9. Kabra, P., McDonald, D. \& Marton, L. (1978) J. Anal. Toxicol. 2, 127-133.

10. Christofides, J. \& Denys, E. (1980) Clin. Chem. 26, 499501.

11. Soldin, S. (1980) Clin. Biochem. 13, 99-101.
Prof. Dr. S. Scharpé Clinical Biochemistry Unit U.I.A. Dpt. Farm. Wet. Universiteitsplein 1, B-2610 Wilrijk Belgium 
